\title{
Performance of arugula genotypes under irrigation depths on Brazilian Cerrado
}

\section{Desempenho de genótipos de rúcula sob lâminas de irrigação no Cerrado brasileiro}

\author{
Fernando França da Cunha ${ }^{1 *}$, Ivan Pereira de Souza ${ }^{2}$, Washington de Oliveira Campos ${ }^{2}$, \\ Valter Carvalho de Andrade Júnior ${ }^{3}$, Thiago Alves Magalhães ${ }^{4}$, Catariny Cabral Aleman ${ }^{1}$
}

\author{
${ }^{1}$ Universidade Federal de Viçosa/UFV, Departamento de Engenharia Agrícola/DEA, Viçosa, MG, Brasil \\ ¿Universidade Federal dos Vales do Jequitinhonha e Mucuri/UFVJM, Unaí, MG, Brasil \\ 3Universidade Federal de Lavras/UFLA, Departamento de Agricultura/DAG, Lavras, MG, Brasil \\ ${ }^{4}$ Universidade Federal de Lavras/UFLA, Departamento de Biologia/DBI, Lavras, MG, Brasil \\ ${ }^{*}$ Corresponding author: fernando.cunha@ufv.br \\ Received in November 1, 2017 and approved in April 23, 2018
}

\begin{abstract}
Due to the water balance in the Brazilian Cerrado, it is not necessary to cultivate arugula in a rainfed system. Together with the lack of research on with this crop, it is necessary to study the response of genotypes to irrigation in this biome. Thus, the objective of this study was to determine the optimal irrigation depth and to identify the best arugula genotypes. Three arugula genotypes were field-tested during two cycles under the effect of four irrigation depths based on crop evapotranspiration. The parameters evaluated were root depth, SPAD index, number of plants and leaves per plant, plant diameter, fresh shoot mass and water use efficiency. The arugula presented the same demand for irrigation in the two cycles, and the genotypes and/or irrigation depths affected the evaluated parameters. The results support that the Folha Larga variety should be preferred by Brazilian Cerrado producers and irrigated with $90 \%$ replacement of crop evapotranspiration.
\end{abstract}

Index terms: Eruca sativa L.; irrigation management; horticultural.

\begin{abstract}
RESUMO
Devido ao balanço hídrico no cerrado brasileiro não permitir cultivo de rúcula em sistema de sequeiro, aliado à inexistência de trabalhos de pesquisa com esta olerícola, cria-se a necessidade de estudar a resposta de genótipos à irrigação neste bioma. Assim, objetivou-se determinar a lâmina ótima de irrigação e identificar os melhores genótipos de rúcula. Três genótipos de rúcula foram testados em campo, durante dois ciclos, sob o efeito de quatro lâminas de irrigação, baseado na evapotranspiração da cultura. Os parâmetros avaliados foram: profundidade de raízes, teor de clorofila foliar, número de plantas e de folhas por planta, diâmetro de planta, massa fresca da parte aérea e eficiência do uso da água. A rúcula apresentou a mesma demanda por irrigação nos dois ciclos e os genótipos e/ou lâminas de irrigações conferiram efeito nos parâmetros avaliados. Os resultados subsidiam que a rúcula Folha Larga deve ser preferida pelos produtores do cerrado brasileiro e irrigada com reposição de $90 \%$ da evapotranspiração da cultura.
\end{abstract}

Termos para indexação: Eruca sativa L.; manejo da irrigação; olericultura.

\section{INTRODUCTION}

The area planted with horticulture in Brazil is estimated at 800 thousand hectares, with a production of approximately 16 million tons (Biscaro et al., 2013). Generally, the production of horticulture concentrates next to large consumption centres, the so-called "green belts". This production is characterized by high perishability and seasonality, and because of these factors, consumption varies throughout the year, a fact that hinders the efficiency of the distribution of these products.

The major consumer of horticultural is the city of Brasilia-DF, the federal capital and the capital of the Cerrado alike, which has a population of approximately
2.8 million people. According to Silva and Costa (2013), $82 \%$ of the population of Brasília-DF consume produce more than five times a week, $24 \%$ of which consume more than three daily servings.

This demand requires a production operation near this city. An alternative is the production of horticulture in the northwest of the State of Minas Gerais, since it shares a border with the Federal District. This region is also contained in the Cerrado biome and stands out for its production of grains and livestock for milk, presenting few initiatives in the cultivation of produce. However, due to this market potential of the Federal District and the increase in the number of rural settlements in this region (Sousa et al., 2011), 
there are good prospects for the production of produce, such as arugula, which is widely used in restaurants and pizzerias of the Federal District.

Arugula, Eruca sativa L., also known as Persian mustard, is a fast-growing crop that has a spicy taste and a pleasant and distinct smell. Arugula originates from the Mediterranean region (Tsirogiannis et al., 2013), and is very popular in the regions of Italian colonization in Brazil, due to its introduction in the country from Italian migration. This vegetable is rich in potassium, sulfur, iron and vitamins A and C (Freitas et al., 2017).

The Minas Gerais northwestern region is in the Brazilian Cerrado biome and presents ideal climatic conditions for the production of arugula, which has become a viable alternative crop (Souza et al., 2016), especially for small producers. However, the existing literature on the agronomic performance of the arugula crop in Brazilian Cerrado conditions, specifically in the northwest of the State of Minas Gerais, is still scarce, and its use is still based on empirical experiments of the producers, lacking references to research results from scientific studies. Therefore, there is a need to study the adaptation of genotypes to the edaphoclimatic conditions of the region, allowing increases in arugula productivity. Many farmers, unaware of this fact, insist on using the same materials that their ancestors used, making the crop less productive and discouraging increased activity.

In addition to choosing the genotype suitable for climate and soil, success in the production of crops depends on the use of irrigation to supply the water needs of the crop in a total or supplementary way. The use of irrigation systems in horticulture is justified by the fact that the irregularity in the pluvial regime becomes restrictive to agricultural development, because even in rainy seasons, periods of water deficit due to evapotranspiration are observed. The evapotranspiration of horticulture generally exceeds rainfall; thus, the adequate distribution of water in an artificial way through irrigation has been the key to production plans, without a lack of rain changing the productivity and profitability indexes that were previously established (Cunha et al., 2013).
In view of the above, the objective of this research was to determine the optimal irrigation depth and to identify the best arugula genotypes for the soil and climatic conditions of the Brazilian Cerrado.

\section{MATERIAL AND METHODS}

Arugula was cultivated in fields under an open sky during two cycles with periods of $38(2 / 28$ to $4 / 7 / 2015)$ and $50(5 / 9$ to $6 / 28 / 2015)$ days. The experiments were conducted in the experimental area of the State School Juvêncio Martins Ferreira, Unaí-MG, Brazil. The geographical coordinates are $16^{\circ} 22^{\prime} 45^{\prime}$ 'S, $46^{\circ} 53^{\prime} 45^{\prime \prime} \mathrm{W}$, and $460 \mathrm{~m}$ altitude. The climate is classified as Aw (with dry winter and maximum rains in the summer), according to the Köppen classification (Souza; Ferreira, 2017), while the annual temperature is between 10 and $35{ }^{\circ} \mathrm{C}$. The average rainfall is $1,200 \mathrm{~mm}$, with concentrated rainfall in summers and dry winters.

The soil of the experimental area is classified as dystrophic Red Yellow Latosol (Empresa Brasileira de Pesquisa Agropecuária - EMBRAPA, 2013), a clayey texture with good drainage. The soil had a specific mass of $1.09 \mathrm{~g} \mathrm{~cm}^{-3}$ and water contents equivalent to the field capacity and a permanent wilting point of the plant of 0.3154 and $0.1820 \mathrm{~cm}^{3} \mathrm{~cm}^{-3}$, respectively.

In order to prepare the ground, a rotating hoe was used throughout the area, and then beds were raised manually using hand hoes at a metre wide. The soil's chemical attributes were determined before each cycle and were carried out at the Laboratory of Chemical Soil Analysis of the Center for Agricultural and Environmental Technology of Paracatu-MG (Table 1). There were no fertilization recommendations, because the nutrient contents were adequate for the arugula cultivation cycles (Sediyama; Salgado; Pinto, 2007).

The experiments were conducted using a randomized complete block design with four replications, in a subdivided plots scheme, with four irrigation depths in the plots and three genotype replications in the subplots. The irrigation depths were used to replace 50, 75, 100 and $125 \%$ of crop evapotranspiration (ETc). The arugula genotypes used were Antonella (Isla), Cultivada (Isla) and Folha Larga (Sakata).

Table 1: Results of chemical analyses of soil in the beginning of the experiment.

\begin{tabular}{|c|c|c|c|c|c|c|c|c|c|c|}
\hline \multirow{2}{*}{ Cycle } & $\mathrm{pH}$ & P & K & $\mathrm{Ca}^{2+}$ & $\mathrm{Mg}^{2+}$ & $\mathrm{Al}^{3+}$ & $\mathrm{H}+\mathrm{Al}$ & CTC & V & $\mathrm{MO}$ \\
\hline & $\cdots \mathrm{H}_{2} \mathrm{O} \cdots$ & \multicolumn{2}{|c|}{ 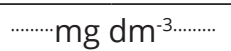 } & \multicolumn{5}{|c|}{$\ldots \ldots \mathrm{cmol}_{c} \mathrm{dm}^{-3 \ldots}$} & \multicolumn{2}{|c|}{$\ldots \ldots \ldots \ldots \ldots \ldots \ldots \ldots \ldots$} \\
\hline 1 & 5.4 & 57.5 & 95.4 & 5.2 & 1.8 & 0.1 & 2.5 & 9.7 & 74.7 & 1.1 \\
\hline 2 & 5.2 & 35.0 & 64.2 & 5.3 & 1.9 & 0.1 & 1.9 & 9.3 & 79.1 & 1.7 \\
\hline
\end{tabular}

$\mathrm{P}$ and $\mathrm{K}$ available with Mehlich I; $\mathrm{Ca}, \mathrm{Mg}$ and $\mathrm{Al}$ extracted with $\mathrm{KCl} 1 \mathrm{~mol} \mathrm{~L}^{-1}$. 
The sample units were composed of plots of 0.8 $\mathrm{m}$ wide and $1.0 \mathrm{~m}$ long, with a total area of $0.8 \mathrm{~m}^{2}$, with 40 plants per plot. The seeding was manual and direct in the field with a spacing of $0.2 \mathrm{~m}$ between rows and 0.05 $\mathrm{m}$ between plants. To do so, micro-grooves were opened in the soil and the seeds were deposited at a depth of 0.5 $\mathrm{cm}$. Seeds were sown on February 28, 2015 (cycle 1), and May 9, 2015 (cycle 2). The thinning was performed 12 days after sowing ( $50 \%$ of the plants had five leaves), maintaining a spacing of $0.1 \mathrm{~m}$ between plants.

The irrigation system, operated by gravity, was dripirrigated, a system that does not water the aerial part of the plants and reduces the risk of contamination, since arugula is a hardy conumed crop (Cordeiro-Araújo et al., 2015). The drip tapes (Petroisa brand) were $16 \mathrm{~mm}$ in diameter. The spacing between the drip tapes was $40 \mathrm{~cm}$, which allowed the irrigation of two rows of plants per lateral line. The emitters operated with a pressure of $98 \mathrm{kPa}(\sim 10 \mathrm{mca})$ applying an approximate flow rate of $1.8 \mathrm{~L} \mathrm{~h}^{-1}$ and were spaced at $20 \mathrm{~cm}$. For the differentiation between treatments with irrigation depths, line-in connectors with registers were used according to the time required to apply the different irrigation levels, open or close the records, and obtain the differentiation of the water in the different treatments.

The irrigation was fixed for each stage of the crop, with the first phase taking one day and the later phases two days. The actual irrigation required for treatment with $100 \%$ ETc water replenishment was defined as a function of the climatic parameters, irrigation system, plant and soil (Equation 1), representing the real water needs of the crops.

$\mathrm{IRN}=\sum_{\text {dial }}^{\mathrm{i}} \mathrm{ET} 0 \mathrm{~K}_{\mathrm{C}} \quad \mathrm{K}_{\mathrm{S}} \quad \mathrm{K}_{\mathrm{L}} \quad-\mathrm{P}_{\mathrm{E}}$

where IRN - actual irrigation required (mm), ET0 - reference evapotranspiration $\left(\mathrm{mm} \mathrm{d}^{-1}\right), \mathrm{K}_{\mathrm{C}}$ - crop coefficient (adm.), $\mathrm{K}_{\mathrm{S}}$ - soil moisture coefficient $\left(\mathrm{adm}\right.$.), $\mathrm{K}_{\mathrm{L}}$ - location coefficient (adm.), and $\mathrm{P}_{\mathrm{E}}$ - effective precipitation in the period (mm).

The Penman-Monteith methodology FAO 56 (Allen et al., 1998) was used to estimate reference evapotranspiration (ET0). The daily meteorological data for ET0 estimation were taken from INMET (National Meteorological Institute), from the station network of Unaí, MG. The variations of the daily meteorological elements in the two cycles of arugula cultivation are presented in Figure 1. The rainfall was obtained by means of a rain gauge installed in the experimental area. The effective precipitation was that used directly by the crop (Bernardo; Soares; Mantovani, 2006), which was the water necessary to raise the current water content at the time of rainfall to the water content equivalent to the field capacity.

The crop coefficients $\left(\mathrm{K}_{\mathrm{C}}\right)$ applied were 0.7 and 1.0 for stages I and III, respectively. For stage II, linear weighting was used between the end of stage I and the beginning of stage III. The durations of stages I and II were 10 days each, and stage III was the 20th day until harvest. The soil moisture coefficient $\left(\mathrm{K}_{\mathrm{S}}\right)$ and location coefficient $\left(\mathrm{K}_{\mathrm{L}}\right)$ were calculated according to Equations 2 and 3, respectively.

$$
\begin{aligned}
& K_{S}=\frac{\operatorname{Ln}(L A A+1)}{\operatorname{Ln}(C T A+1)} \\
& K_{L}=\frac{P}{100}+0,15\left(1-\frac{P}{100}\right)
\end{aligned}
$$

where $\mathrm{K}_{\mathrm{S}}$ - soil moisture coefficient (adm), LAA - current soil water depth (mm), CTA - total soil water capacity ( $\mathrm{mm}$ ), $\mathrm{K}_{\mathrm{L}}$ - location coefficient (adm.), and $\mathrm{P}$ - highest value between the percentage of wet or shaded area (\%).

The IRN value was corrected according to the irrigation efficiency of the system, defining the total required irrigation (ITN) according to Equation 4. The irrigation efficiencies in cycles 1 and 2 were 92.5 and $89.7 \%$, respectively.

$I T N=\frac{I R N}{E i}$

where ITN - total required irrigation (mm), IRN - actual irrigation required ( $\mathrm{mm}$ ), and Ei - irrigation efficiency (dec.).

Crops were collected on April 7, 2015 (cycle 1), and June 28, 2015 (cycle 2). The parameters used to evaluate the treatments in the arugula culture were as follows:

Depth of roots $(\mathrm{cm})$ : obtained through the opening of a lateral trench between the plants using a hoe. After removal of the largest possible root depth, the soil adhered to the roots was removed, and the plant was taken to measure the distance between the collar and root end using a $0.1-\mathrm{cm}$ scale ruler. This analysis was performed in six plants previously identified at the beginning of the cycles.

SPAD index: obtained by means of a portable electronic meter (Chlorophyllometer, model SPAD 502, manufactured by KONICA MINOLTA SENSING, INC. (Konica Minolta, 2009)) per plant, in fully developed and healthy leaves.

Number of plants $\left(\mathrm{ud} \mathrm{m}^{-2}\right)$ : the total number of plants harvested in each plot, where the value refers to plant units in the plots. 

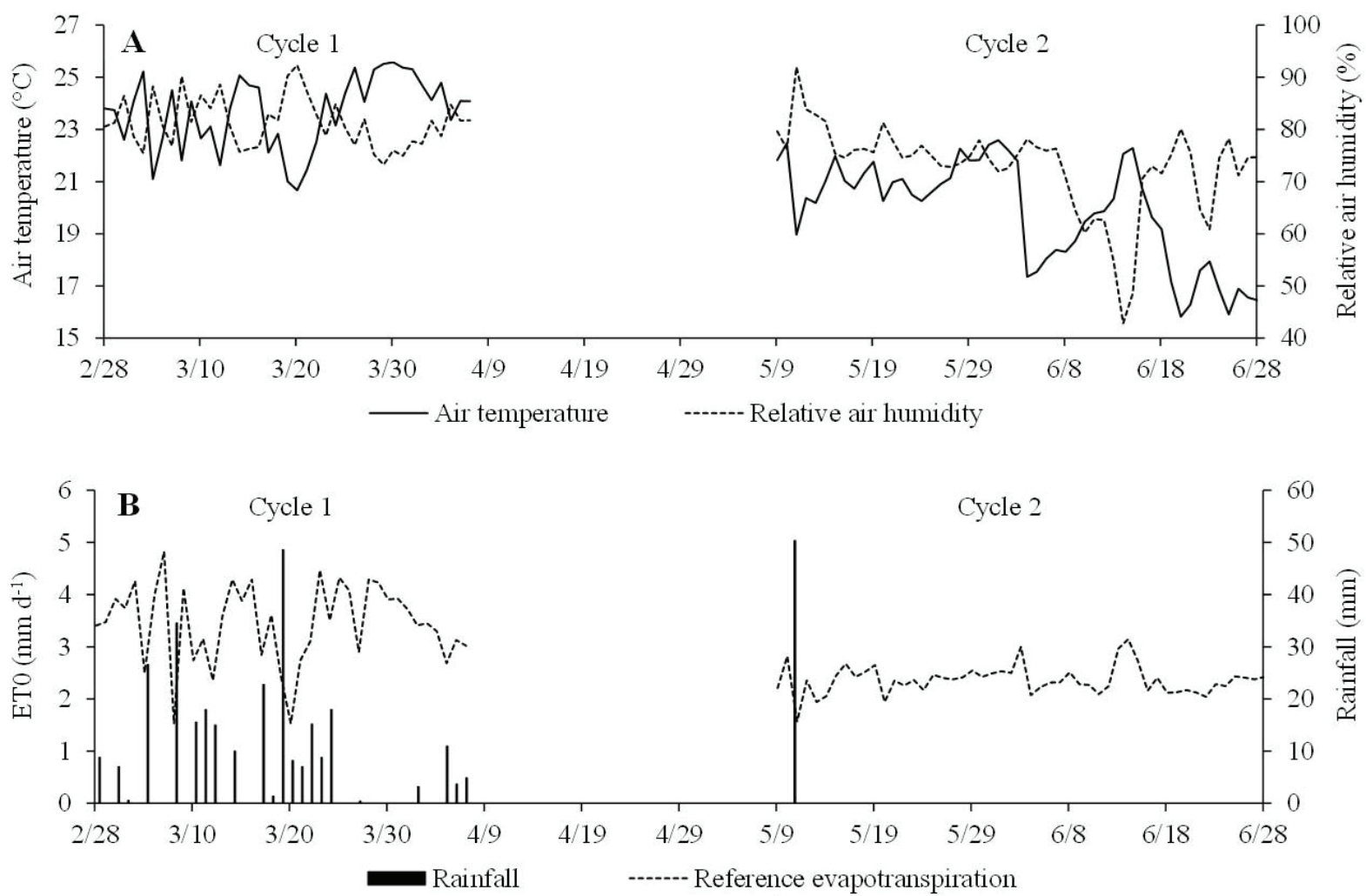

Figure 1: Daily variation of $(\mathrm{A})$ air temperature $\left({ }^{\circ} \mathrm{C}\right)$, relative air humidity $(\%),(\mathrm{B})$ reference evapotranspiration $\left(\mathrm{mm} \mathrm{d}^{-1}\right)$ and rainfall $(\mathrm{mm})$ for the two cycles of arugula cultivation.

Number of leaves per plant (ud plant $\left.\mathrm{t}^{-1}\right)$ : the number of leaves that were able to be marketed per plant; that is, they were not damaged and were over $3 \mathrm{~cm}$ in length. This analysis was performed in six plants of each plot.

Plant diameter $(\mathrm{cm})$ : measured by means of a ruler from one end to another in six plants corresponding to the diameter of a circumference.

Aerial fresh mass $\left(\mathrm{kg} \mathrm{m}^{-2}\right)$ : obtained by means of the relation between the mass of all plants of the plot after removal of the roots and the area of the experimental unit.

Water use efficiency $\left(\mathrm{kg} \mathrm{m}^{-3}\right)$ : obtained by the relationship between the fresh mass of the aerial part in the plot and the amount of water applied.

Data were submitted to analysis of variance and regression. The comparison of means was performed using the Tukey test at $5 \%$ probability. For quantitative factors, linear and quadratic models were tested. The selection of the model was based on the significance of the regression coefficients, using the $t$ test at $5 \%$ probability, for the coefficient of determination $\left(\mathrm{R}^{2}\right)$ and the biological phenomenon. In the execution of the statistical analysis, we used the experimental package R software Designs
3.3.2 (R Development Core Team, 2016). Multivariate techniques of principal components analysis (PCA) were also performed using Genes software (Cruz, 2013).

\section{RESULTS AND DISCUSSION}

The arugula presented the same demand hydric in the two crop cycles (Table 2). Although cycle 1 presented higher evapotransprometric rates (Figure 1B), cycle 2 had a duration of 12 days. Effective precipitation, according to Bernardo, Soares and Mantovani (2006), is that fraction of the precipitation used directly by the crop; that is, it is the amount of water that the plant uses in its physiological processes. The difference between the effective precipitation and the total precipitation was the amount of water that leaked superficially and percolated below the root system of the crop after the soil immediately above reached the water content equivalent to the field capacity. In the treatment of $100 \%$ irrigation depth of the ETc of cycle 1, for example, only $42.2 \mathrm{~mm}$ was considered effective out of the $289.4 \mathrm{~mm}$ of water added to the soil via rainfall, meaning the amount that was available in soil for the culture. This low utilization was due to the high 
frequency of irrigation, and the precipitation occurred in periods when the arugula had lower values of Kc. In this way, the soil always remained close to its field capacity, requiring a low amount of water to reach the total storage capacity.
There was an interaction between genotypes and irrigation depths for root depth in cycle 1 (Table 3 ). Regardless of the irrigation depth, the Folha Larga arugula presented higher root depths. It was also verified, in cycle 1 , that the irrigation depths provided root depth reduction

Table 2: Effective precipitation, actual irrigation required and total water depth applied at each treatment and arugula cultivation cycle.

\begin{tabular}{ccrrrr}
\hline \multirow{2}{*}{ Cycle } & \multirow{4}{*}{ Event } & \multicolumn{4}{c}{ Irrigation depth } \\
\cline { 3 - 5 } & & $50 \%$ ETc & 75\% ETc & $100 \%$ ETc & $125 \%$ ETc \\
\hline \multirow{2}{*}{1} & Effective precipitation $(\mathrm{mm})$ & 46.3 & 44.1 & 42.2 & 42.2 \\
& Actual irrigation required $(\mathrm{mm})$ & 31.8 & 47.8 & 63.7 & 79.6 \\
& Total water depth $(\mathrm{mm})$ & 78.1 & 91.9 & 105.9 & 121.8 \\
\multirow{2}{*}{2} & Effective precipitation $(\mathrm{mm})$ & 5.2 & 4.8 & 4.5 & 4.5 \\
& Actual irrigation required $(\mathrm{mm})$ & 50.8 & 76.2 & 101.6 & 127.0 \\
& Total water depth $(\mathrm{mm})$ & 56.0 & 81.0 & 106.1 & 131.5 \\
\hline
\end{tabular}

Table 3: Mean values of root depth (RD), SPAD index, number of plants (NP), number of leaves per plant (NLP), plant diameter (PD), aerial fresh mass (AFM) and water use efficiency (WUE) according to different genotypes and irrigation depths in two cycles of cultivation of arugula.

\begin{tabular}{|c|c|c|c|c|c|c|c|c|c|}
\hline \multirow{2}{*}{ Factor } & \multirow{2}{*}{ Cycle } & \multirow{2}{*}{$\begin{array}{l}\text { CV } \\
(\%) \\
\end{array}$} & \multicolumn{3}{|c|}{ Teste $\mathrm{F}$} & \multirow{2}{*}{$\begin{array}{l}\text { Irrigation } \\
\text { Depth }\end{array}$} & \multirow{2}{*}{$\begin{array}{c}\text { Antonella } \\
\text { Isla }\end{array}$} & \multirow{2}{*}{$\begin{array}{l}\text { Cultivada } \\
\text { Isla }\end{array}$} & \multirow{2}{*}{$\begin{array}{c}\text { Folha Larga } \\
\text { Sakata }\end{array}$} \\
\hline & & & ID & $A G$ & ID*AG & & & & \\
\hline \multirow{5}{*}{$\begin{array}{l}\mathrm{RD} \\
(\mathrm{cm})\end{array}$} & \multirow{4}{*}{1} & \multirow{4}{*}{20.3} & \multirow{4}{*}{$117.2^{* \star \star}$} & \multirow{4}{*}{$33.94^{\star * *}$} & \multirow{4}{*}{$11.19^{* *}$} & $50 \%$ ETc & $20.9 a$ & $17.0 \mathrm{~b}$ & $23.0 \mathrm{a}$ \\
\hline & & & & & & $75 \%$ ETC & $16.6 \mathrm{~b}$ & $19.9 a$ & $20.0 \mathrm{a}$ \\
\hline & & & & & & $100 \%$ ETc & $16.8 \mathrm{a}$ & $14.8 \mathrm{a}$ & $17.1 \mathrm{a}$ \\
\hline & & & & & & $125 \%$ ETc & $13.3 \mathrm{ab}$ & $11.6 \mathrm{~b}$ & $14.8 \mathrm{a}$ \\
\hline & 2 & 16.8 & $15.93^{\text {ns }}$ & $15.12^{\text {ns }}$ & $10.00^{\text {ns }}$ & & & $\hat{y}=15.2$ & \\
\hline SPAD & 2 & 14.0 & $371.6^{* * *}$ & $7.021^{\mathrm{ns}}$ & $10.95^{\text {ns }}$ & & & $\hat{y}=43.1$ & \\
\hline \multirow{5}{*}{$\begin{array}{c}N P \\
\left(u d m^{-2}\right)\end{array}$} & 1 & 18.9 & $72.82^{\star \star \star}$ & $1.290^{\mathrm{ns}}$ & $0.792^{\mathrm{ns}}$ & & & $\hat{y}=54.7$ & \\
\hline & \multirow{4}{*}{2} & \multirow{4}{*}{24.1} & \multirow{4}{*}{$345.3^{* *}$} & \multirow{4}{*}{$436.3^{* *}$} & \multirow{4}{*}{$118.6^{*}$} & $50 \%$ ETC & $56.9 \mathrm{a}$ & $67.5 \mathrm{a}$ & $61.9 \mathrm{a}$ \\
\hline & & & & & & $75 \%$ ETc & $55.6 \mathrm{a}$ & $43.1 \mathrm{a}$ & $50.0 \mathrm{a}$ \\
\hline & & & & & & $100 \%$ ETc & $75.6 a$ & $73.1 \mathrm{a}$ & $77.5 \mathrm{a}$ \\
\hline & & & & & & $125 \%$ ETc & $70.6 \mathrm{~b}$ & $92.5 \mathrm{a}$ & $74.4 \mathrm{~b}$ \\
\hline \multirow{2}{*}{ 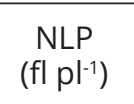 } & 1 & 31.5 & $72.82^{* * \star}$ & $1.290^{\mathrm{ns}}$ & $0.792^{\mathrm{ns}}$ & & & $\hat{y}=7.96$ & \\
\hline & 2 & 27.6 & $79.70^{\star \star *}$ & $5.951^{\text {ns }}$ & $2.662^{\mathrm{ns}}$ & & & $\hat{y}=9.51$ & \\
\hline \multirow{2}{*}{$\begin{array}{l}\mathrm{PD} \\
(\mathrm{cm})\end{array}$} & 1 & 23.4 & $67.73^{\star * \star}$ & $0.080^{\text {ns }}$ & $3.093^{\mathrm{ns}}$ & & & $\hat{y}=10.62$ & \\
\hline & 2 & 16.0 & $20.97^{\star \star *}$ & $6.309^{\text {ns }}$ & $2.150^{\mathrm{ns}}$ & & & $\hat{y}=12.10$ & \\
\hline \multirow{2}{*}{$\begin{array}{c}\text { AFM } \\
\left(\mathrm{kg} \mathrm{m}^{-2}\right)\end{array}$} & 1 & 30.3 & $4.319^{* \star *}$ & $0.029^{\text {ns }}$ & $0.101^{\text {ns }}$ & & & $\hat{y}=1.73$ & \\
\hline & 2 & 19.4 & $0.467^{* *}$ & $0.205^{*}$ & $0.095^{\mathrm{ns}}$ & & $1.48 a b$ & $1.37 \mathrm{~b}$ & $1.60 \mathrm{a}$ \\
\hline \multirow{2}{*}{$\begin{array}{c}\text { WUE } \\
\left(\mathrm{kg} \mathrm{m}^{-3}\right)\end{array}$} & 1 & 32.7 & $402.4^{\star * \star}$ & $3.060^{\text {ns }}$ & $10.19^{\text {ns }}$ & & & $\hat{y}=17.65$ & \\
\hline & 2 & 29.0 & $275.8^{* *}$ & $17.61^{\text {ns }}$ & $8.377^{\text {ns }}$ & & & $\hat{y}=17.04$ & \\
\hline
\end{tabular}

${ }^{*} p<0.05 ;{ }^{* *} p<0.01 ;{ }^{* * *} p<0.001 ;{ }^{\text {ns }}$ not significant. Means followed by the same letter in a line do not differ by Tukey's test $(p<0.05)$. 
in all arugula genotypes (Figure 2). It is possible that the crop in the treatments with smaller irrigation depth deepened its root system to extract water in lower layers of the soil.

There was an isolated effect of the irrigation depth on the SPAD index of the arugula (Table 3 ). Figure 3 shows the quadratic behaviour of the SPAD index in response to irrigation depth. According to the regression equation, the $62 \%$ irrigation depth of Etc maximized the SPAD index of the arugula, resulting in the value of 47.6 SPAD. The increase in the SPAD index results from the development of chloroplasts and the consequent increase in nitrogen content in the leaf (Piekielek; Fox, 1992; Smeal; Zhang, 1994). It was demonstrated in this study that water availability is of fundamental importance in this process. Thus, it is suggested that the irrigation depth of $62 \%$ of Etc was the one that provided the best water condition at that moment when the SPAD index was measured. Abdalhi et al. (2016) observed the same behaviour for cucumbers in China, where the authors applied irrigation depths from 50
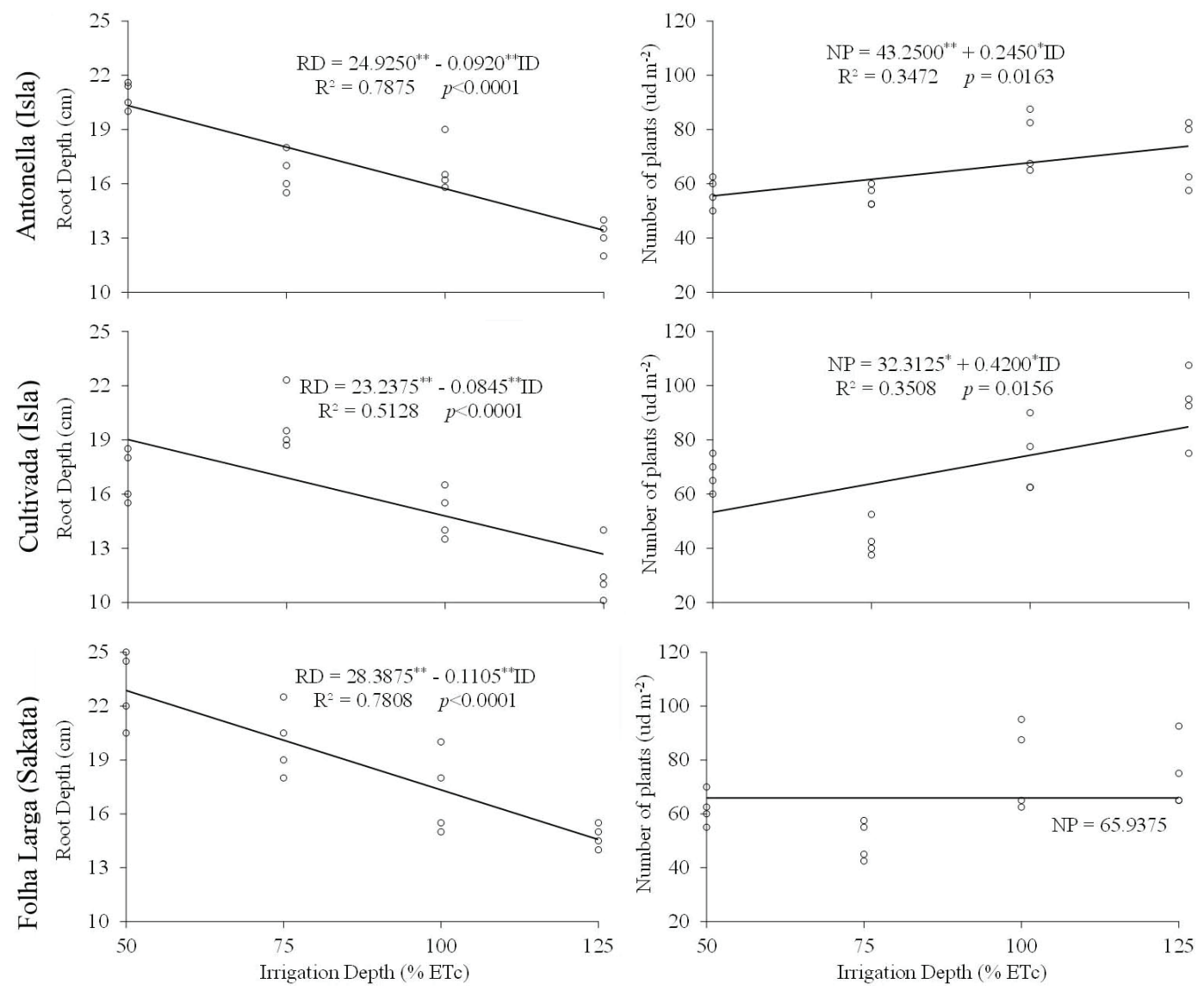

Figure 2: Estimates of root depth (RD) in cycle 1 and number of plants (NP) in cycle 2 as a function of irrigation depths (ID) for different arugula genotypes. 
effect, since the higher number of plants in this treatment resulted in a higher water withdrawal rate and a soil with higher free porosity than the other genotypes.

Irrigation depths provided a linear positive effect in the Antonella and Cultivada genotypes in cycle 2 (Figure 2) and in all genotypes in cycle 1 (Figure 3 ). Thus, it is suggested that the larger irrigation depths provided a larger plant stand.

The genotypes did not confer an isolated or interaction effect on the number of leaves per plant and plant diameter in any cycle of the arugula. On the other hand, the irrigation depths provided an isolated effect on these parameters in all cycles performed (Table 3 ). In cycle 1 , the irrigation depths provided a quadratic effect on the number of leaves of the arugula (Figure 4). According to the regression equation, the $93 \%$ ETc maximized the number of leaves per plant of the arugula, resulting in a value of 10.8 leaves per plant. Moline et al. (2015) applied irrigation depths varying from 50 to $110 \%$ of Etc in the Cultivada arugula in Vilhena-RO and found higher values of the number of commercially viable leaves in the treatment with irrigation depth with $100 \%$ replacement of ETc. Vasco et al. (2011) applied different irrigation depths in the genotype Folha Larga in the city of Itabaiana-SE and verified that the irrigation depth that maximized the number of commercial leaves of arugula was $94.9 \%$ of the ETc. In cycle 2, the irrigation depths provided a positive linear effect on the number of leaves per plant of the arugula (Figure 4).

The irrigation depths provided a quadratic effect on the diameter of the arugula in both cycles (Figure 4). According to the regression equations, irrigation depths of 80 and $72 \%$ of ETc maximized the plant diameter of the arugula, resulting in values of 12.8 and $12.9 \mathrm{~cm}$ for cycles 1 and 2, respectively. The plant diameter is influenced by the number of leaves, which can be observed in cycle 1 where these parameters presented the same behaviour. However, in cycle 2, the number of plants presented linear behaviour and a quadratic response in plant diameter. It is possible that this happened due to the greater competition for radiation caused by the increase in plants in the larger irrigation depths, resulting in smaller plant diameters under these conditions. With the increase in the consumption of minimally processed arugula (washed and chopped), it is worthwhile to harvest larger plants whose larger diameter can represent greater profit for the producer.

There was an isolated effect of the genotype on the fresh mass of the aerial part of the arugula in cycle 2, where the genotype Folha Larga did not differ from Antonella but was superior to the Cultivada (Table 3). In view of this, the Folha Larga arugula is preferred in relation to the others for cultivation in the Brazilian Cerrado. This same recommendation was made by Cunha et al. (2013) for the edaphoclimatic conditions of Chapadão do Sul-MS. Linhares et al. (2017) also found good performance of this genotype in concert with carrot and coriander in Mossoró-RN. However, it is worth mentioning that more research should be carried out with these genotypes and others on the market for conclusions about and recommendations for greater certainty.

The irrigation depths provided an isolated effect on the fresh mass of the aerial part of the arugula in the two cycles (Table 3). In this way, it was possible to adjust the quadratic regression equation for the two cycles (Figure 4), where the 90 and 94\% ETc depths maximized the arugula productivity, resulting in values of 2.35 and $1.64 \mathrm{~kg} \mathrm{~m}^{-2}$ in cycles 1 and 2, respectively. In light of this, it is recommended to irrigate arugula in the edaphoclimatic conditions of the Brazilian Cerrado with a
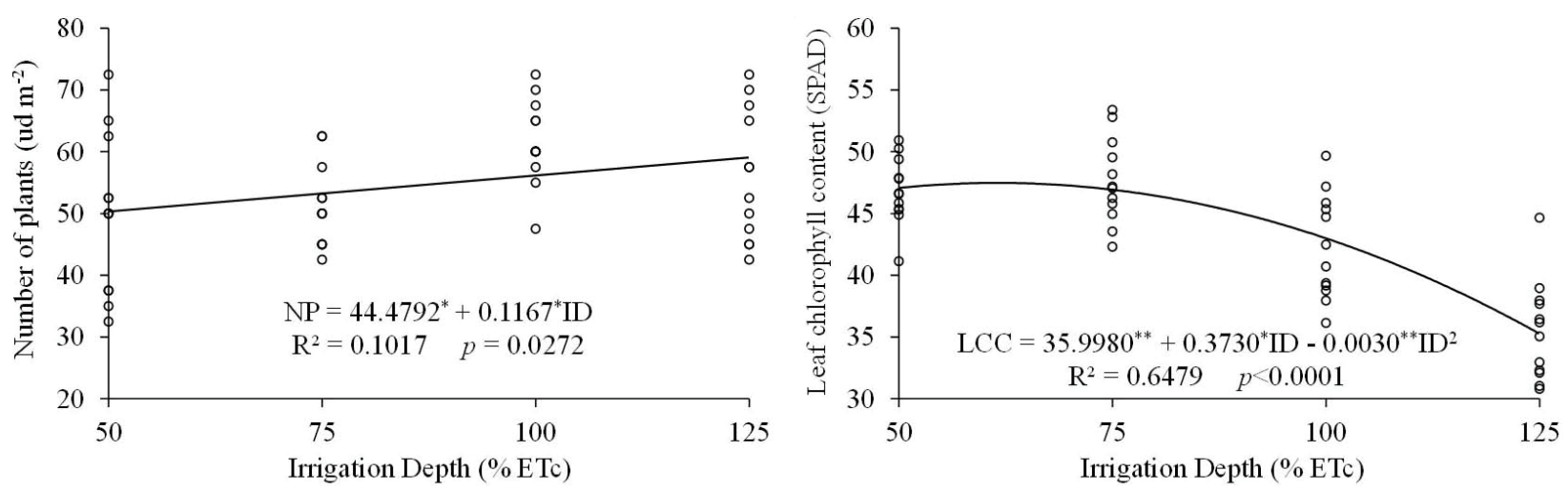

** and * significant at 1 and $5 \%$ probability, respectively.

Figure 3: Estimates of the number of plants (NP) in cycle 1 and SPAD index in cycle 2 of the arugula with consideration of the irrigation depth (ID). 
depth to supply $90 \%$ of the ETc. Under these conditions, water and electricity are saved in the production of arugula in order to increase its economic viability.

Moline et al. (2015) applied irrigation depths varying from 50 to $110 \%$ of ETc and found greater productivities of arugula with the $100 \%$ ETc. Vasco et al. (2011) applied irrigations varying from 50 to $125 \%$
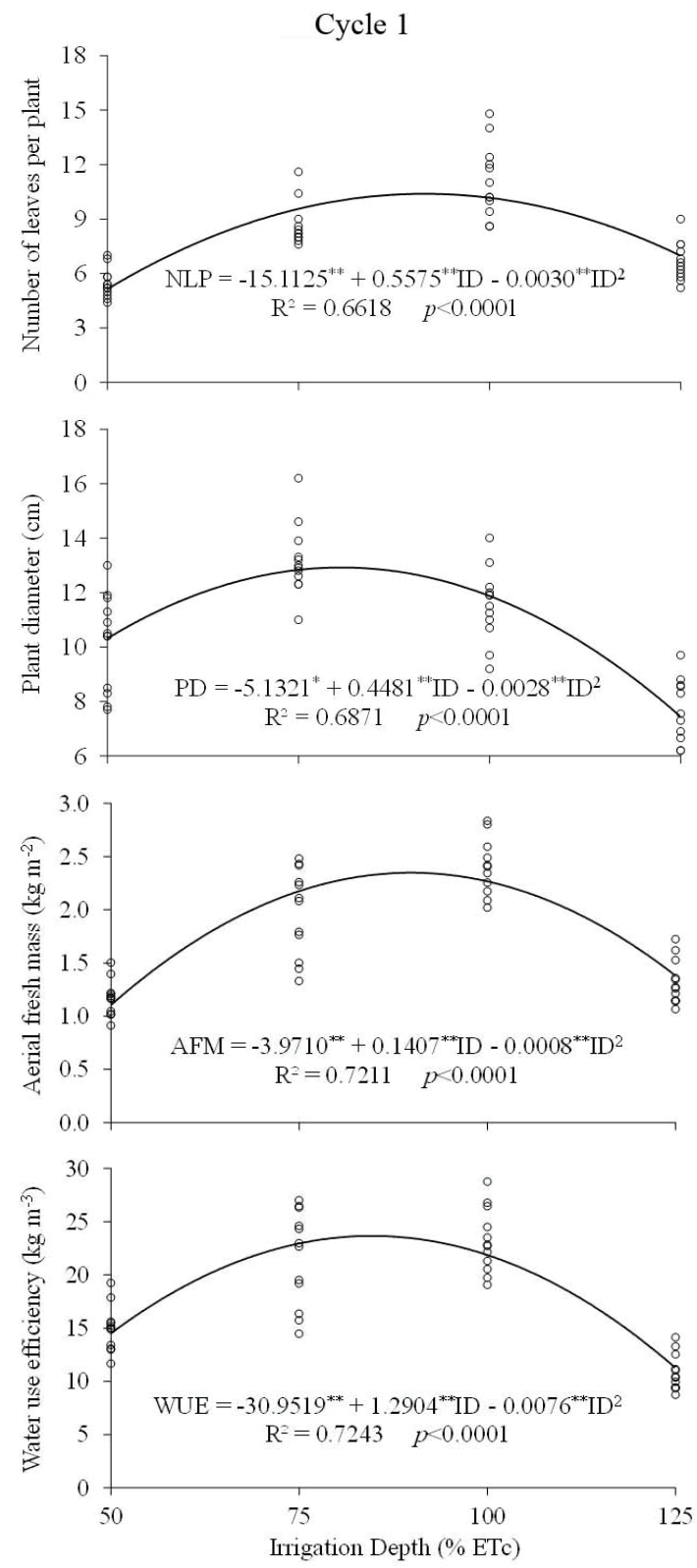

** and $*$ significant at 1 and $5 \%$ probability, respectively.

Figure 4: Estimates of the number of leaves per plant (NLP), plant diameter (PD), aerial fresh mass (AFM) and water use efficiency (WUE) considering the irrigation depth (ID) for the two crop cycles of arugula. 
There was an isolated effect of the irrigation depths on the water use efficiency (WUE) by the arugula in the evaluated cycles (Table 3 ). Figure 4 shows the quadratic behaviour of the WUE in response to the irrigation depths, where the $85 \% \mathrm{ETc}$ provided the highest WUE value $\left(23.7 \mathrm{~kg} \mathrm{~m}^{-3}\right)$. This result indicates that to produce $1 \mathrm{~kg}$ of fresh mass of arugula leaves, 42.2 litres of irrigation water are needed.

In cycle 2 , the irrigation depths conferred a negative linear effect (Table 3 ) because these factors are inversely proportional, corroborating the results of Freitas et al. (2017) in which different irrigation depths were applied to Cultivada arugula in Viçosa-MG.

Principal components analysis (PCA) was performed with two principal components (PCs) (Figure 5). In PC 2, the factors were the number of leaves per plant and fresh mass of the aerial part, and PC 1 included the other factors. It is verified in the PCA that the irrigation depths of 75 and $100 \%$ presented the best results. With regard to genotypes, Cultivada presented better results in PC 1, and Antonella performed better in PC 2. However, the Folha Larga arugula in both PCs also performed well.

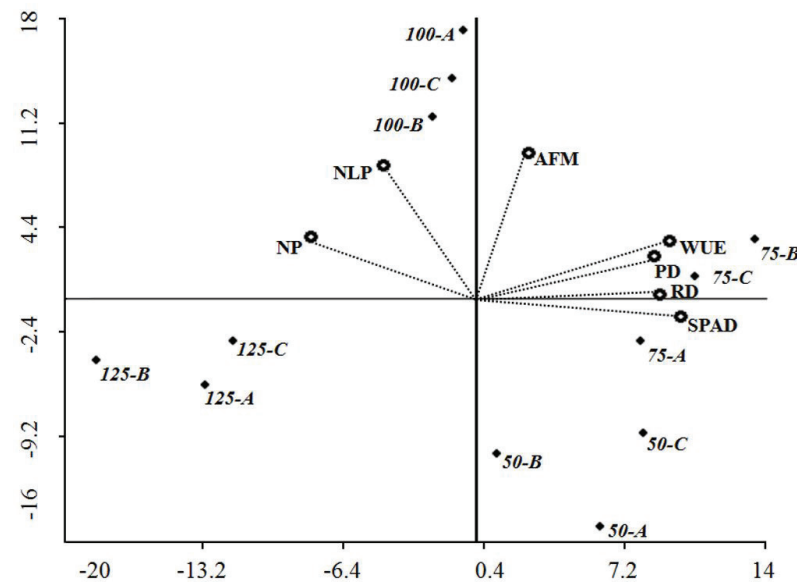

Figure 5: Two-dimensional projection of irrigation depths $(50,75,100$ and $125 \%$ of ETc), genotypes (A - Antonella, B - Cultivada and C - Folha Larga) and evaluated characteristics of arugula: root depth (RD), SPAD index, number of plants (NP), number of leaves per plant (NLP), plant diameter (PD), aerial fresh mass (AFM) and water use efficiency (WUE).

\section{CONCLUSION}

The Folha Larga arugula genotype should be preferred by the producers of the Brazilian Cerrado and regions with similar conditions and should be irrigated with $90 \%$ of crop evapotranspiration.

\section{ACKNOWLEDGMENTS}

The authors would like to thank FAPEMIG, CNPq and CAPES for the financial support.

\section{REFERENCES}

ABDALHI, M. A. M. et al. Performance of drip irrigation and nitrogen fertilizer in irrigation water saving and nitrogen use efficiency for waxy maize (Zea mays L.) and cucumber (Cucumis sativus L.) under solar greenhouse. Grassland Science, 62(3):174-187, 2016.

ALLEN, R. G. et al. Crop evapotranspiration: Guidelines for computing crop water requirements. Rome: FAO, 1998. 297p. (Irrigation and Drainage Paper, 56).

BERNARDO, S.; SOARES, A. A.; MANTOVANI, E. C. Manual de Irrigação. 8 ed. Viçosa: Editora UFV, 2006. 625p.

BISCARO, G. A. et al. Produtividade e análise econômica da cultura do espinafre em função de níveis de fertirrigação nitrogenada. Irriga, 18(4):587-596, 2013.

CORDEIRO-ARAÚJO, M. K. et al. Selective membrane permeability and peroxidase activity response of lettuce and arugula irrigated with cyanobacterial contaminated water. Environmental Earth Sciences, 74(2):1547-1553, 2015.

CRUZ, C. D. Genes: A software package for analysis in experimental statistics and quantitative genetics. Acta Scientiarum. Agronomy, 35(3):271-276, 2013.

CUNHA, F. F. et al. Irrigação de diferentes cultivares de rúcula no nordeste do Mato Grosso do Sul. Water Resources and Irrigation Management, 2(3):131-141, 2013.

EMPRESA BRASILEIRA DE PESQUISA AGROPECUÁRIA EMBRAPA. Sistema brasileiro de classificação de solos. 3 ed. Brasília: Embrapa, 2013. 306p.

FREITAS, E. M. et al. Arugula production as a function of irrigation depths and potassium fertilization. Revista Brasileira de Engenharia Agrícola e Ambiental, 21(3):197-202, 2017.

KONICA MINOLTA SENSING, INC. Chlorophyll meter SPAD502Plus. Osaka: Instruction manual, 2009. 6p.

LINHARES, P. C. A. et al. Polycultures of coriander, carrot, and arugula in strip-intercropping system. Caatinga, 30(3):622632, 2017.

MOLINE, E. F. V. et al. Diferentes lâminas de irrigação na cultura da rúcula no sul de Rondônia. Nucleus, 12(1):371-378, 2015.

MACHEKPOSHTI, M. F. et al. Effect of irrigation with sea water on soil salinity and yield of oleic sunflower. Agricultural Water Management, 188(1): 69-78, 2017. 
PIEKIELEK, W. P.; FOX, R. H. Use of a chlorophyll meter to predict sidedress nitrogen requirements for maize. Agronomy Journal, 84(1):59-65, 1992.

PUTTI, F. F. et al. Response of lettuce crop to magnetically treated irrigation water and different irrigation depths. African Journal of Agricultural Research, 10(22):2300-2308, 2015.

R DEVELOPMENT CORE TEAM. R: A language and environment for statistical computing. Vienna: Foundation for Statistical Computing, 2016.

SEDIYAMA, M. A. N.; SALGADO, L. T.; PINTO, C. L. O. Rúcula. In: PAULA Jr.; T. J.; VENZON, M. (ed.). 101 Culturas: Manual de tecnologias agrícolas. Belo Horizonte: EPAMIG. p.683686. 2007.

SILVA, C. L.; COSTA, T. H. M. Barreiras e facilitadores do consumo de frutas e hortaliças em adultos de Brasília. Scientia Medica, 23(2):68-74, 2013.

SMEAL, D.; ZHANG, H. Chlorophyll meter evaluation for nitrogen management in corn. Communications in Soil Science and Plant Analysis, 25(9):1495-1503, 1994.
SOUSA, D. N. et al. A dinamização dos assentamentos rurais para o desenvolvimento econômico do Noroeste de Minas Gerais. Revista de Ciências Humanas, 11(1):8797, 2011.

SOUZA, E. G. F. et al. Agronomic response of arugula to green fertilization with rooster tree during two culture times. African Journal of Agricultural Research, 11(48):49314938, 2016.

SOUZA, J. E. B.; FERREIRA, E. P. B. Improving sustainability of common bean production systems by co-inoculating rhizobia and azospirilla. Agriculture, Ecosystems and Environment, 237(1):250-257, 2017.

TSIROGIANNIS, I. L. et al. Relationships between reflectance and water status in a greenhouse rocket (Eruca sativa Mill.) cultivation. European Journal of Horticultural Science, 78(6):275-282, 2013.

VASCO, A. N. et al. Irrigation management in real time for arugula crop in Sergipe. Journal of Agricultural Science and Technology, 13(12):1161-1167, 2011. 